\title{
SOCIAL AND CULTURAL IMPACTS ON THE PREGNANT WOMAN
}

\author{
L. Perusanova - Pavlova* \\ Medical Faculty, Sofia University "St. Kliment Ohridski ", Sofia, Bulgaria
}

\begin{abstract}
Introduction: The pregnant woman regardless of physiological changes continues to be a part of the public system. She remains a part of her family, place of work and continues to meet those social roles that have characterized her before the pregnancy.

The aim of the study is to identify the social and cultural impacts during the prenatal period causing increased anxiety and stress.

Materials and Methods: An anonymous survey of 120 pregnant women attending antenatal care in four hospitals in the country: Hospital "St.Vrach" Sandanski, University Hospital "Rockefeller" Petrich , Department of Obstetrics and Gynaecology at the University Hospital "Lozenets " Sofia and University Hospital " Maichin dom "Sofia. The survey was conducted in 2014.

Results and conclusions: The factors with the greatest impact during the pregnancy are the low income, the determination to live "close to the bottom" and "below average" social class. The stress and greater responsibilities in the workplace come in addition, plus a fear of a dismissal and a lack of support from the partner. Keeping certain rituals and cultural traditions is a "counterpoint" to many fears and the anxiety of the pregnant woman.
\end{abstract}

Key words: social impacts, family environment, pregnancy, partner, traditions, stress

\section{INTRODUCTION}

The pregnant woman regardless of physiological changes still remains part of the public system. Social impacts on the pregnant woman may be: the effects of family environment; -effects of the working environment on pregnant; - Effects resulting from social status and the dominant tradition in the specific cultural environment (30, p.115).

\section{Effects of family environment}

Family environment as a social institute is the first social subsystem, which most significantly affected by the impending birth. She expects the emergence of a new member along with it even before the child is born it gets a role in a family (33, p.201). This role can be dominant, but can also be neglected depending on the situation that the child will have in the family and the dominant culture and traditions in a given society.

As a rule, the social status of the future child also affects pregnant. Depending on the accepted

\footnotetext{
*Correspondence to: Lilia Perusanova - Pavlova, Assistant professor in Medical Faculty, Sofia University "St. Kliment Ohridski", 1407 Sofia, Bulgaria, St. Kozyak 1, e-mail liliperusanova@abv.bg, tel. 0878905539
}

conventions her social status can be changed in connection with delivery of pregnancy (43). In this connection, the social status of the pregnant woman creates (even in the most favorable conditions and a high degree of loyalty to her family and the family of the father) implicitly defined tensions both between it and "close" and family (the father of the child and family which expectant lives) and among pregnant and "widespread" family (between the pregnant woman and other relatives in the family) (19, p.83). This tension is caused by the hypothetical nature of the qualities of a future child of the possible difficulties associated with child rearing, as well as its capacity to meet those social expectations that has the family as a social structure to it. Important is what the previous social experiences of a family in raising children. If the family environment has a positive social experience associated with older children in the family, then the degree of social tension is significantly lower (1, p.210).

Along with the sense of tension that arises from the expectation of future family member, the family can have a significant positive impact on pregnant. This positive aspect is the support of both the "narrow" and "wide" family, help the pregnant to realize the social importance of its function as a future mother (19a, p.111). 
Working environment Impacts

Regardless of what form of labor activity occurs pregnant woman changes her physical condition have a direct impact on this aspect of its social contacts. High levels of anxiety can be motivated by purely objective factors:

- Ignorance of the peculiarities of the legal regulation of the situation of the young mother;

- Concerns relating to child rearing;

- The risk of loss of work due to pregnancy and childbirth and others. (30, p.77)

New physical sensations, new psychological environment in which the mother is creating significant uncertainties in relations with different categories of people with whom she has working contacts $(39$, p.112).

If a woman receives support from her family, she can rely on him and materially, especially in the social aspect, concerns arising from the breach or modifying social contacts retreat into the background overcome by the influence of the importance of the social function of the mother.

\section{Impact of social status of the mother}

In the practice of every society there is a certain social stratification that defines the social status of the individual, as well as those social institutions and their characteristics to which a person is relevant (6, p.210).

Motherhood brings significant changes in some of the most important social institutions affecting pregnant. In turn, the social status of the mother determined by the stratification of society significantly influence these institutions and therefore the impact on pregnant $(6, \mathrm{p} .188)$.

Notwithstanding the different cultures can make a general conclusion regarding social status, namely to the higher social category belongs the mother, the more important it is for the future birth of a child (1, p.177, 2 p.201-203).

\section{Cultural dominance embedded in the traditions of society}

Bulgarian centuries knew and did her best to give birth to healthy and beautiful children. During pregnancy is filled with many things that it is better to do, and more so, and perhaps more prohibitions. Pregnant limited by different foods and activities, which in most cases is determined by a direct connection imitation, albeit quite external to what it wants to avoid the woman for himself and the child. Restrictions are both health care for the mother and child, but also a kind of isolation and precaution. Very strong emphasis on the moral prohibitions $(15, \mathrm{p} .14)$.

Prohibitions introduced national tradition as to certain foods that the woman should abstain during pregnancy and certain prohibitions against women.

So women should not eat back her husband after a trip bread to not be the future where cowardly wild or domestic animal killed by a wolf is not the future baby hairy; fish head or gills of fish, not snore or snort the child while sleeping; turtle meat, to avoid startling dream.

The tradition provides for the promotion of certain foods that should be used pregnant - to drink goat's milk with honey and wine, eat heel of bread in order to have a male child (15, p.16).

There are certain prohibitions concerning pregnant. So pregnant should not be a road not to be angry the Virgin and Child to be born abnormal, and not to smash his head; pregnant women should not be scared, not like a child who scares her - human or animal, for a pregnant woman should not talk at night to not hear it from evil demons and "throw the child" and the woman to miscarry.

The tradition recommends certain actions of the pregnant:

- To remove yourself from every evil pregnant should in the first weeks of pregnancy to descend body soap naked;

- Pregnant women should bathe more often to avoid crying infant;

- Pregnant woman should honor some of the strictest church holidays - St. Anna, Virgin Mary, St. Simeon, St. Barbara and St. Ignatius' Day; when the child move for the first time in the womb, woman should mixtures a cake (white wheat flour) to break up into pieces and distribute it to friends and relatives to the child, to born easily and the child to be healthy (15 p.18-21).

The aim of the study was to determine which social and cultural impacts in prenatal period cause in women voltage changes in the relationship with the partner, stress in the workplace and increased anxiety.

\section{MATERIALS AND METHODS}

An anonymous survey of 120 pregnant women attending antenatal care in four hospitals in the country: Hospital "St.Vrach" Sandanski, Hospital "Rockefeller" Petrich, Department of Obstetrics and Gynecology at the University Hospital " Lozenets " Sofia and University Hospital " Maichin dom " Sofia. The survey was conducted in 2014

\section{DISCUSSION}

1. Age distribution of pregnant: Pregnant under 20 are 14 , aged 20 to $30 \mathrm{~g}$ - 45 pregnant women, 30 to $40 \mathrm{~g}-54$ and over age 40 are 7 women. 
2. Social class affiliation. $33.33 \%$ of respondents consider that live near the bottom, $58.34 \%$ live a little above average, but only $8.33 \%$ that live well. 3. Unemployment rate. $75 \%$ of pregnant women are employed, $25 \%$ are unemployed.

4. Education. With secondary education are $41.67 \%$ of pregnant women with higher $55.83 \%$ with primary education $-2.5 \%$

5. Level of income. With an average income (from 500-1000lv) are $61.66 \%$ of respondents, $25 \%$ have high incomes (over 1000lv), $13.33 \%$ are low-income (260-500lv).

6. Marital status. $71.67 \%$ are married respondents in partnerships $28.33 \%$. No single mothers and divorced pregnant.

7. Religion. Orthodox are $95 \%$ of women, Muslim women are $3.33 \%$ and atheists define $1.67 \%$.

8. Stressful situations in the workplace. All respondents indicated that they have experienced stressful situations in the workplace.

9. Overload in the workplace and lack of time. A significant proportion of respondents - 93.33 percent indicated that they were overwhelmed at the workplace during pregnancy and lack of time.

10. Assigning fewer responsibilities at work. $80,00 \%$ of respondents would like to have less job responsibilities in a gestation period.

11. Support partner. Significantly lower (21.67\%) is the percentage of pregnant women who have felt the support from your partner.

12. Independent home. In a separate dwelling live 80.83\% percent of respondents.

13. Healthy Eating. Half of the surveyed pregnant women believe that eating healthy.

14. Sufficient sleep and rest. $94.17 \%$ of women think that they suffer from lack of sleep and rest.

15. Document for temporary incapacity for work before going on leave. $65 \%$ of pregnant women would use hospital.

16. Danger of dismissal or redundancy during pregnancy. More than half $-54.17 \%$ of the women feel threatened by dismissal or redundancy.

17. In which way the woman is pregnant. $85.00 \%$ of the women were pregnant with their first child.

18. Respect for traditions and rituals during pregnancy. All respondents have observed certain rituals and traditions during her pregnancy.

19. The types of traditions, rituals, customs and beliefs are described in the free text of pregnant women in questionnaires:

Avoid knit to not wrap the cord around the baby, Do not go home in the dark, If you want something to eat, they should eat to not miscarry, When first the woman felt fetal movement should be appropriateness loaf, Yes do not be frightened and startled pregnant woman, By the third month not to tell anyone she was pregnant, If after the fifth month of a gestation period kept secret child, Would be deaf and dumb if pregnant steal something to eat to touch a covered part of the body, not to scar, Do not eat rabbit meat to not cowardly child, Wear a red thread on his left hand against the evil eye, To have a boy to eat corner of bread, Carry wrapped woolen belt at the waist to give birth slightly, Do not cross the path of the pregnant woman, Pregnant not to kill a snake, When I left to bear not to tell anyone to give birth slightly, Until bed at night puts pregnant broom to chase evil spirits, If pregnant refuse food, it the child will be a fussy eater, Pregnant not to look at anything ugly and scary to not affect the appearance of the baby, Do not quarrel with anyone pregnant woman, because the child will be nervous, Pregnant not to play with cats, because one day the child there will be many enemies, Never woman before the baby is born cannot buy clothes, lest there be an accident at birth, Pregnant should not be shot or drawing to be born healthy baby, Pregnant woman hair is not clipped to not cut luck baby, Pregnant does not jump cables and hoses to not wrap the cord around the baby's neck, Pregnant not to eat snails and not sissy child, Where throw navel baby there will run his life, Like go to a pregnant gave birth to open all cabinets and drawers can be easily birth, If a pregnant woman wants something to eat and it will not lick your hand, not miscarry.

\section{FINDINGS AND CONCLUSIONS}

$\checkmark \quad$ Disturbing fact is that half of respondents do not eat healthily, and the majority suffer from insufficient sleep and rest and excessive burden on the workplace.

$\checkmark \quad$ Optimal physiological age of first birth is 24 to 30 years, but half of pregnant women aged between 30 and 40 years, which shows that a woman is planning the birth of a child after receiving education and is materially stable.

$\checkmark$ Only $15 \%$ of women pregnant with a second child, which confirms the trend of reducing the birth rate in Bulgaria

$\checkmark \quad$ Social class affiliation is an influential factor for the Bulgarian before a child $-58.34 \%$ live a little above average, $33.33 \%$ of respondents consider that live near the bottom. Material well-being of the mother would create comfort and sense of security in caring for a newborn.

$\checkmark \quad$ Employment security is an important factor in the creation of generation in Bulgarians. $75 \%$ of pregnant women are employed, 25\% unemployed.

$\checkmark$ During the pregnancy $80 \%$ of women prefer to be loaded with less job responsibilities, and $65 \%$ would use sick leave before the 45 -day maternity leave. All women indicated that their workplace had stressful situations.

$\checkmark \quad$ More than half of pregnant women fear redundancy and dismissal in the workplace, and this factor, together with the lack of support from the partner pregnant evokes feelings of 
insecurity and anxiety. Support from partners in connection with the new social role of women is crucial for the successful outcome of pregnancy.

$\checkmark \quad$ Marriage and partnership are an integral part of the traditions of women in Bulgaria - no single mothers and divorced in the survey. $71.67 \%$ are married respondents in partnerships $28.33 \%$.

$\checkmark$ Observance of rituals and traditions creates a certain psychological comfort on the pregnant woman, regardless of its level of education or what is the nature of its activities. All surveyed pregnant, which has not complied with any custom or may have resorted to some ritual. Even in the cases where the mothers say they do not "believe" the many folk traditions and customs compliance represents a certain "counterpoint" to the many fears that have the mother during her pregnancy.

$\checkmark \quad$ Culture has a significant impact on the course of pregnancy and the attitudes of the mother. The variety of cultural products and suggests various options such as effects on the pregnant with this one of the institutes of culture - the beliefs and customs have an effect notwithstanding the pregnant to one or another social category.

\section{REFERENCES}

1. Антонов А. Медков В. Социология семьи. МУБУ, 1996 г.

2. Батуев А. С., Соколова Л. В. Биологическое и социальное в природе человека / Под ред. А. С. Батуева // Биосоциальная природа материнства и раннего детства. - СПб.: СПбГУ, 2007

3. Боровикова Н. В. Психологические аспекты трансформации Я-концепции беременной женщины // Перинатальная психология и нервно-психическое развитие детей: тезисы конференции 27 мая 1998

4. Боровикова Н. В. Акмеологический потенциал беременной женщины. Социально-психологический анализ. - М.: Социнновация, 1998

5. Воронов М. Психосоматика, „Ника-Центр”, 2002

6. Гофман А.Б. Семь лекций по истории социологии, КДУ, 2008

7. Добряков И. В. Профилактика дидактогений, психологогений и ятрогений в работе с беременными женщинами // Мать, ребенок, семья: современные проблемы: Сборник материалов научнопрактической конференции / Под ред. И. В. Добрякова. СПб.: Комитет по здравоохранению администрации СанктПетербурга, Центр медицинской профилактики, 2000

8. Добряков И. В. Типология гестационной доминанты // Ребенок в современном
мире:Тезисы докладов 3-й международной конференции. - СПб.: ЮНЕСКО, МО России, 1996.,

9. Добряков И. В. Формирование раннего диалога матери и младенца в разные стадии жизнедеятельности семьи // Материалы конгресса по детской психиатрии., Москва, РОСИН-ЭКС, 2001.

10.Добряков И.В. Перинатальная психология, М. - Питер, 2005 г.,

11.Кацулов А. Нормално акушерство, София , „Венел”, 1993 г.,

12.Малкина-Пых И. Г. Психосоматика. Справочник практического психолога. Эксмо, 2005

13.Минченков А.В. Елпидифоров П.Б. Методы структурной психосоматики, ЮВЕНТА, 2001

14.Мясищев В. Н. Основные проблемы и современное состояние психологии отношений человека // Психология отношений: Избранные психологические труды. Москва, Институт практической психологии; Воронеж: НПО «МОДЭК», 1995.

15.Старева Л. Български обичаи и ритуали. Труд. 2005 г.

16.Старшенбаум Г.В. Психосоматика и психотерапия. Исцеление души и тела, Издательство института психотерапии, 2005 г.

17.Федор-Фрайберг П. Пренатальная и перинатальная психология и медицина: новая междисциплинарная наука в меняющемся мире // Феномен насилия (от домашнего до глобального): взгляд с позиции пренатальной и перинатальной психологии и медицины / Под ред. проф. Г. И. Брехмана и проф. П. Г. ФедорФрайберга. - СПб., 2005.

18.Филиппова Г. Г. Материнская потребностно-мотивационная сфера поведения / Сборник материалов конференции по перинатальной психологии. - М., 1998

19.Фрейд 3. Введение в психоанализ: Лекции. Москва, Наука, 1989

19а. Черняк Е. Социология семьи. Дашков и К, 2004 г.

20.Эйдемиллер Э. Г., Добряков И. В. Клиникопсихологические методы семейной диагностики и семейная психотерапия: Методические рекомендации., СПб.: МАПО, 2001.

21.Ainsworth M. D. S. Attachment: Retrospect and prospect // Parkes C. M., Stevenson - Hide L. (ed.) The pleace of attachment in human behavior. - N. Y.: Academ. Press, 1983

22.Barber J. S., Axinn W. G., Thornton A. Unwanted childbearing, health, and mother- 
child relationships / J Health Soc Behav., 1999., Vol. 40., № 3.

23.Bongaarts J. Do Reproductive Intentions Matter // International Family Planning Perspectives. 1992. V. 18. № 3.

24.Gabbe S. G. et al. (eds.) Normal and Problem Pregnancies (6th ed.) Saunders / Elsevier, 2012

25.Hamilton-Fairley Lecture notes: on obstetrics and gynaecology, Blackwell Publishing, 2004

26.Keith Edmonds Dewhurst's Textbook of Obstetrics and Gynaecology, Wiley-Blackwell, 2012

27.Kephart W.M., Jedlicka D. The Family, Society and Individual. New York, 1991.

28.Lundy B., Jones N. A., Field T. et al. Prenatal depression effects on neonates. - Infant Behav. Dev. 1999.

29.Michael De Swiet Medical Disorders in Obstetric Practice, 4th edition, Blackwell Science, 2002

30.Murphy M.Y. The Family Life Cycle // Readings in Population Research Methodology. V. 4. Chicago, 1993.

31.Peseschkian N. Die Bedeutung sozialer Normen in der positiven Psychotherapie unter dem transkurellen Gesichtspunkt. Habilitationsschrift, Frankfurt ат Main, 1987, p.135.

32.Pines D. A. Woman's Unconscious Use of Her Body. New Haven: Yale University Press,1994.;
33.Pajulo M., Savonlahti E., Sourander A. et al. Antenatal depression, substance dependency and social support. J. Affect Disord. 2001., p.213.

34.Raphael-Leff J. Pregnancy. The Inside Story. London: Karnak, 2001., p.49

35.Raphael-Leff J. Psychological Processes of Childbearing. Fourth Edition. London: The Anna Freud Centre, 2005., p.332.

36.Sabshin M Wendepunkt in der amerikanischen Psychiatrie des 20. Jahrhunderts. Fortschr Neurol Psychiat, 1991

37.Samantha M. Pfeifer, MD NMS Obstetrics and Gynecology, 7th Edition, Lippincott Williams \& Wilkins, 2011

38. Schindler S., Zimprich H. Ekologie der Perinatalzeit. - Stuttgart: Hippocrates, 1983.

39. Schmale AH, Iker HP The psychological setting of uterine cervical cancer. Ann New York, 1994

40.Schusser G. Zur Problematik einer dichotomischen Erclarung der Eruhesten Mutter-Kind-Interaction //Symposion neue Erkenntnisse. - Universitat Osnabruck, 1988.

41.Spielberger C. D. Anxiety and behavior. N. Y., Academic Press, 1966.,

42.Toy E.C. Case Files: Obstetrics and Gynecology, 2nd Edition, McGraw-Hill, 2007

43. Winnicott, D. The theory of the parent-child relationship., Int. J. Psychoanal. Acad Sei 1966 